\title{
RESOURCE ABUNDANCE AND DISTRIBUTION DRIVE BEE VISITATION WITHIN DEVELOPING TROPICAL URBAN LANDSCAPES
}

\author{
Victoria Wojcik ${ }^{1,2 *}$ \\ ${ }^{1}$ Pollinator Partnership, 423 Washington Street 5th Floor, San Francisco, CA 94111 \\ ${ }^{2}$ University of California, Berkeley, Department of Environmental Science, Policy, and Management, Berkeley, CA 94720
}

\begin{abstract}
Urban landscapes include a mix of biotic and anthropogenic elements that can interact with and influence species occurrence and behaviour. In order to outline the drivers of bee (Hymenoptera: Apoidea) occurrence in tropical urban landscapes, foraging patterns and community characteristics were examined at a common and broadly attractive food resource, Tecoma stans (Bignoniaceae). Bee visitation was monitored at I20 individual resources in three cities from June 2007 to March 2009. Resource characteristics, spatial distribution, and other local and regional landscape variables were assessed and then used to develop descriptive regression models of forager visitation. The results indicated that increased bee abundance and taxon richness consistently correlated with increased floral abundance. Resource distribution was also influential, with more spatially aggregated resources receiving more foragers. Individual bee guilds had differential responses to the variables tested, but the significant impact of increased floral abundance was generally conserved. Smaller bodied bee species responded to floral abundance, resource structure, and proximity to natural habitats, suggesting that size-related dispersal abilities structure occurrence patterns in this guild. Larger bees favoured spatially aggregated resources in addition to increased floral abundance, suggesting an optimization of foraging energetics. The impact of the urban matrix was minimal and was only seen in generalist feeders (African honey bees). The strongly resource-driven foraging dynamics described in this study can be used to inform conservation and management practices in urban landscapes.
\end{abstract}

Key Words: $\quad$ urban ecology, foraging, resource characteristics, Tecoma stans, bees (Hymenoptera), Costa Rica

\section{INTRODUCTION}

Bees (Hymenoptera: Apoidea) and other pollinators are facing global survival challenges that are attributed in part to local anthropogenic change (NRC 2007). Land use intensification, particularly in the form of agricultural and urban development, has been shown to diminish the nesting and foraging habitats of native bees, resulting in decreases in abundance and changes in pollinator function (Kremen et al. 2002; Buchmann \& Ascher 2005). In recent years, Northwestern Costa Rica has experienced an increase in urban development linked to growth in tourism, international business, manufacturing, and agriculture. Changes in bee community composition that correspond to local fragmentation have already been recorded (Frankie et al. 1997) and are particularly evident at the edge of urban development (Frankie et al. 2009a). Investigating how bees respond to urbanization is imperative given the everincreasing rate of landscape conversion and their importance as pollinators to nearly $90 \%$ of tropical floral species (Ollerton et al. 20II) and over 30\% of the crops that make up the human diet (Buchmann \& Nabhan 1996).

Recent studies focusing on urban bees have documented species occurrences (Owen I99I; Frankie et al. 2002), examined community composition with respect to general

Received 3I January 20II, accepted 3I March 20I I

${ }^{*}$ Corresponding author; telephone: cell 510-697-3890; office 4I5-362-II37; email: vw@pollinator.org;

victoriawojcik@hotmail.com land use patterns (Saure 1996; McIntyre \& Hostetler 200I; Cane et al. 2006; Nates-Parra et al. 2006; Matteson et al. 2008), and evaluated trends in floral host usage and preferences (Hismatsu \& Yamane 2006; Antonini et al. 2006; Frankie et al. 2005). Although it is clear that bees are resident and abundant in some urban landscapes, field observations and published works show their distribution to vary. Nearby cities in the same regional landscape can have significantly different resident bee faunas (Frankie et al. 2009b). Within individual cities variability in bee community structure has been noted in different land use types, such as residential areas (Winfree 2007) and community gardens (Matteson et al. 2008), and with respect to the size and age of habitat remnants (Cane et al. 2006). Changes in bee community structure (Lui \& Koptur 2003) and absolute bee numbers have also been recorded along urban-natural gradients (Ahrne et al. 2009), as have seasonal transitions driven by shifts in resource availability (Cane et al. 2005).

Both landscape context and local site variables can influence bee occurrences and foraging patterns. In the highly modified landscapes of central Europe the overall landscape composition was found to be more influential in determining honey bee occurrences than site-specific variables (SteffanDewenter \& Kuhn 2003). A similar trend was reported by Heard et al. (2007) for bumble bees foraging within different agro-environments. Nearness to intact forest habitat was also noted to be more important than local land management in determining the number of bees expected at local coffee plantations in the tropical dry forest of Costa Rica (Brosi et 


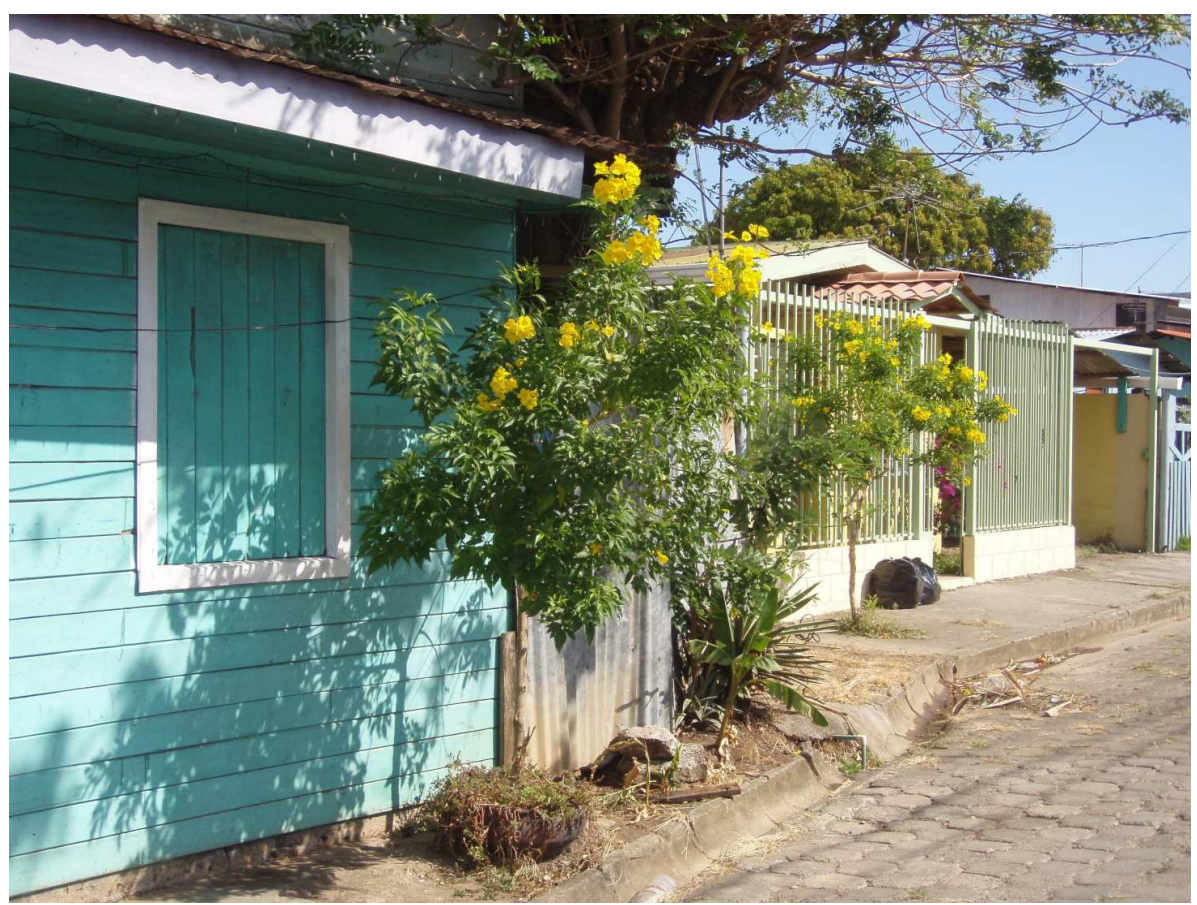

FIG I: A common street view showing two $T$. stans resources within the urban matrix (Cañas, Costa Rica). al. 2007). In contrast, Collevatti et al. (2000) showed that the quality and quantity of resources present at a patch determined foraging patterns, irrespective of the local landscape. Bee assemblages are functionally diverse and factors that impact the community might not necessarily have analogous effects on individual groups and species. For example, Jha and Vandermeer (2009) recorded contrasting responses to resource variables and local habitat variables between native bees and non-native honey bees foraging in coffee plantations in central Mexico. Foraging patterns might also be driven by different variables in natural and anthropogenic systems, but they have yet to be investigated in sufficient detail to make generalized statements.

The goal of this study is to achieve a better understanding of how resource characteristics and local landscape variables structure the foraging patterns of bees in urban ecosystems. The following analysis aims to: (I) describe and model the factors that are influencing bee visitation to food resources in a tropical dry forest urban system and (2) to examine these factors at the community level and in terms of individual bee guilds to see if congruent or contrasting patterns emerge. The system of bees visiting Tecoma stans, a common and preferred food resource in this region, is used as a model. Distance to wildland habitats, proximity to other landscape features (riparian areas and open space), land use type (residential versus commercial), local resource characteristics (floral abundance and life form), and resource distribution are examined for their effect on abundance and richness. Within the mix of variables that might be influencing resource usage in cities are those that are unique to urban landscapes, such as residential and commercial land use and the separation of a site from the wildland habitat by the urban matrix. A parallel focus of this analysis is to determine to what extent these 'urban'factors impact bee resource usage.

\section{MATERIALS AND METHODS}

\section{Site description}

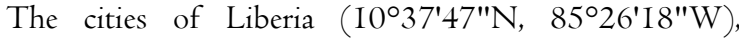
Bagaces (10॰31'34"N, $\left.85^{\circ} 15^{\prime} 18^{\prime \prime} \mathrm{W}\right)$, and Cañas $\left(10^{\circ} 25^{\prime} 36^{\prime \prime} \mathrm{N}, 8^{\circ} 05^{\prime} 28^{\prime \prime} \mathrm{W}\right)$ lie in a row along Central America Highway I in the Guanacaste province of Costa Rica. These three cities are characteristic of urban development in the region, displaying a trend of increasing peripheral growth due to increased commercial and residential demands. Liberia covers $7.97 \mathrm{~km} 2$, Bagaces covers $0.76 \mathrm{~km} 2$, and Cañas covers $2.98 \mathrm{~km} 2$. The most recent census data puts the urban population of Liberia, the provincial capital, at 34,469; Bagaces at 3,645; and Cañas at I6,5I2 (INEC 2000).

\section{Regional landscape classification}

Tropical dry forest was the dominant habitat in this region prior to urbanization and agricultural development. Today, habitat has been fragmented to varying degrees by cattle ranching, agriculture, and commercial development, however there are remnant areas of savannah. Ranching was dominant around both Bagaces and Liberia, but these two cities were also in closer proximity to a network of biological reserves and conservation areas. Cañas was surrounded by more intensive irrigated agriculture.

\section{Urban landscape classification}

A combination of satellite images, GIS data, and ground observations were used to code urban land use and landscape characteristics. Appendix I provides the summary statistics and abbreviations for the variables used. All spatial calculations were preformed in ArcMap 9.3 (C) (ESRI Inc. 2009, Chicago IL). The Near Feature tool was used to calculate the distance of each $T$. stans to the wildland-urban 
interface (D WUI) and nearest riparian area (D RIP). The Nearest Neighbour tool was used to find the closest conspecific $T$. stans individual. The number $T$. stans individuals within radii of $10 \mathrm{~m}, 50 \mathrm{~m}$, and $100 \mathrm{~m}$ were calculated by constructing corresponding buffer polygons and using the Points in Polygon tool in the Hawth's Tools package. Proximity to open space (OPEN) was coded as present when the floral resource was on or adjacent to a city block that contained unmanaged open spaces (e.g., large yards, vacant lots) and public parks or fields. A residential classification (RES) was given when the dominant use on the block was either single or multifamily housing. A commercial designation (COM) was given when the dominant use consisted of either public or private business, shopping, government offices, banks, and parking lots.

\section{Floral resource characterization}

The yellow trumpet tree, Tecoma stans Kunth (Bignoniaceae) is a common mass-flowering woody perennial found across Costa Rica, and much of the tropics. The native range in the Americas extends from the south central and southeastern United States (Arizona to Florida) down into Argentina (Hammel 2005; Zuchowski 2007). T. stans was ubiquitous and well distributed in the three landscape studied here and multiple morphologies were common due to variation in pruning and management. Although $T$. stans produces flowers year-round, the most intense flowering occurs between November and March. Fig. I depicts a common residential street view where multiple $T$. stans resources are present within the urban matrix.

Previous work has indicated that $T$. stans attracts a wide range of bee species from multiple feeding, social, and size guilds that account for approximately $10 \%$ of the local wildland bee species diversity (Wojcik 2009). The majority of these bee species are in the genus Centris and have been observed to collect both pollen and nectar (see Wojcik 20II). The pollination system of T. stans in Central America has yet to be studied in detail. Work from South America identified Centris tarsata Smith and Exomalopsis fulvofasciata Smith as effective pollinators in Brazil (Silva et al. 2007). The size and behaviour of the most abundant visitor to T. stans in Northwestern Costa Rica, C. eurypantana Snelling, suggest that it could be an effective pollinator (pers. obs.). Other large bodied species such as Ephicharis elegans and Eulema sp. could be potential pollinators, but are not common visitors. Halictus and Lasioglossum species that visit this resource do not appear to be effective pollinators based on their size and behaviour (pers. obs.)

A survey of each city catalogued all visible $T$. stans individuals using a hand-held GARMIN Vista C etrex GPS unit. In total, I47 individuals were marked, of which 120 were easily accessible from public land and were used in the study. Each individual resource was photographed digitally for visual reference, character coding, and resource metric estimation. Height (HEIGHT) and crown width (CROWN) at the widest part of the crown were estimated from the referenced photographs to the nearest $25 \mathrm{~cm}$. Each individual was also coded into three life form classes (SHRUB, HEDGE, or TREE) depending on shape and growth habit.
A stratified sub-sample of the canopy was used to estimate the number of flowers (FLW) per individual $T$. stans. The canopy of each resource was fractioned into a manageable sector based on overall size $(2,4,8$, or 10 sectors); this fraction was then used as an expansion factor $(k)$. The total number of inflorescences (i) in one randomly selected sector was counted. A subsample $(n=5)$ of inflorescences was used to calculate the average number of flowers per inflorescence $(f)$. The calculated average number of flowers per inflorescence was then multiplied by the number of inflorescences and the expansion factor as follows: FLW $=f \times i \times k$. In the case of some individual resources with very few flowers the total number of flowers was enumerated using a census.

TAB I: Bee species comprising the taxonomic categories used for analysis and model development. The relative occurrence of each species in the cities of Bagaces, Cañas, and Liberia is indicated as common $(\mathrm{C})$, rare $(\mathrm{R})$, or known from a single record $(\mathrm{S})$ based on collections made over the study period.

\begin{tabular}{|c|c|c|c|}
\hline \multirow[t]{2}{*}{ Species } & \multicolumn{3}{|c|}{ Location } \\
\hline & Bacages & Cañas & Liberia \\
\hline \multicolumn{4}{|l|}{ Solitary Large } \\
\hline Ancyloscelis sp. & $\mathrm{R}$ & - & $\mathrm{R}$ \\
\hline $\begin{array}{l}\text { Augochlora nigrocyanea } \\
\text { Cockerell }\end{array}$ & $\mathrm{C}$ & $\mathrm{C}$ & $\mathrm{C}$ \\
\hline Centris aethyctera Snelling & $\mathrm{C}$ & $\mathrm{C}$ & - \\
\hline Centris eurypatana Snelling & $\mathrm{C}$ & $\mathrm{C}$ & $\mathrm{C}$ \\
\hline Centris heithausi Snelling & $\mathrm{C}$ & $\mathrm{C}$ & - \\
\hline Epicharis elegans Smith & - & - & $\mathrm{C}$ \\
\hline Euglossa viridissima Friese & $\mathrm{C}$ & $\mathrm{C}$ & $\mathrm{C}$ \\
\hline Eulemasp. & $\mathrm{S}$ & - & $\mathrm{C}$ \\
\hline Xylocopa fimbriata Fabricius & $\mathrm{R}$ & $\mathrm{C}$ & $\mathrm{C}$ \\
\hline $\begin{array}{l}\text { Xylocopa subvirescens } \\
\text { Cresson }\end{array}$ & - & - & $\mathrm{C}$ \\
\hline \multicolumn{4}{|l|}{ Solitary Small } \\
\hline Agapostemon nasutus & - & - & S \\
\hline Halictus lutescens Friese & $\mathrm{C}$ & $\mathrm{C}$ & $\mathrm{C}$ \\
\hline Lasioglossum Dialictus sp.I & - & $\mathrm{C}$ & - \\
\hline Lasioglossum Dialictus sp.2 & - & $\mathrm{C}$ & - \\
\hline \multicolumn{4}{|l|}{ Native Eusocial } \\
\hline $\begin{array}{l}\text { Nannotrigona perilampoides } \\
\text { Cresson }\end{array}$ & $\mathrm{C}$ & $\mathrm{C}$ & $\mathrm{C}$ \\
\hline Plebeia frontais Friese & $\mathrm{R}$ & - & $\mathrm{R}$ \\
\hline Tetragonisca angustata Lep. & $\mathrm{C}$ & - & $\mathrm{C}$ \\
\hline $\begin{array}{l}\text { Trigona fulviventris Guérin- } \\
\text { Méneville }\end{array}$ & $\mathrm{C}$ & $\mathrm{C}$ & $\mathrm{C}$ \\
\hline $\begin{array}{l}\text { Non-native Eusocial } \\
\text { Apis mellifera scutellata } \\
\text { Latreille }\end{array}$ & $\mathrm{C}$ & $\mathrm{C}$ & $\mathrm{C}$ \\
\hline
\end{tabular}




\section{Bee monitoring and identification}

Bee visitation was documented from June 2007 to March 2009. Visitor abundance and richness were measured at each resource within a standardized one by one metre square observation frame that was visually projected onto an easily observable and unobstructed area of the floral resource. The visitation rates of bees to all of the flowers within this visual frame were recorded for the duration of three minutes. Eight evenly spaced counts occurred throughout the day between $0800 \mathrm{~h}$ and $\mathrm{I} 400 \mathrm{~h}$ in order to account for temporal variability in bee occurrence (see Wojcik 20II). Samples were repeated across multiple days (at least four) and in both the wet and dry seasons. Bees were identified on-the-wing to one of four categories: large solitary, small solitary, native eusocial, or non-native eusocial bees. A list of the species that comprise each taxonomic category and their documented occurrences in each city is presented in Tab. I. Bee identification was assisted by Laurence Packer and Jason Gibbs of York University, Toronto, Canada and by Ricardo Ayala of Universidad Nacional Autónoma de México.

\section{Statistical analysis}

The average number of bees and the average number of different taxon groups recorded per three-minute count were calculated for each resource from all of the counts taken during the entirety of the study period. The visitation rates of each bee group, the abundance, and the taxon richness were compared between the three cities using multivariate ANOVA followed by pairwise comparisons with Tukey's HSD in order to determine if parallel patterns existed in each landscape. A Bonferroni adjusted $\alpha$ of $0.016(0.05 / 3)$ was used to reduce Type I error.

The averaged count data were checked for normality using both normal-quartile plots and the Shapiro-Wilk test. The untransformed data plotted within a normal distribution, with some wobble at the ends of the distribution, but the results from the Shaprio-Wilk test were less then $p=0.05$, indicating a deviation from the normal distribution. Subsequent standard data transformations were performed (log, square root, arcsine, etc.), but neither the plotted fit nor the Shaprio-Wilk statistic changed significantly. Given the large size of the data set $(n>30)$, a decision was made to use the untransformed data for the analysis. An analysis of covariance was used to assess the independence of the variables in their description of bee visitation patterns. The variable CROWN was found to be highly correlated with FLW and was removed from the regression analysis. The remaining thirteen variables were independent in their explanation of the data. Regional and city specific descriptive models were generated for abundance, taxon richness, solitary bees (large and small) and eusocial bees (native and nonnative), and for each individual bee group (large solitary bees, small solitary bees, native eusocial bees, and non-native eusocial bees) using backward stepwise regression with $\mathrm{p}=$ 0.10 as the entrance criterion and $p=0.05$ as significant. A total of 32 models were generated in this manner. Model selection was based on significant improvement in fit $(r 2$ value) and $\triangle A I C$, favouring simpler models with fewer variables when significant changes were not present in the analytical metrics. All of the statistical analyses were performed in SPSS I6.0 (C) Chicago IL 2007).

\section{RESULTS}

\section{General and site-specific foraging patterns}

Patterns of overall abundance and richness varied significantly between the three cities $\left(\mathrm{F}_{2,2083}=4.94, \mathrm{p}=0.007\right.$ and $F_{2,2083}=19.50, p=0.000$, respectively). Abundance ranged from 0 to 32 bees observed per count, with a mean of $3.55 \pm$ I.OI (mean \pm S.E) and was highest in Liberia. Richness ranged from 0 to 4 bee types per count, with a mean of $1.35 \pm 0.73$ and was again higher in Liberia. Pairwise comparison with Tukey's HSD indicated that large native solitary bees $\left(\mathrm{F}_{2}=\mathrm{I} 8.68, \mathrm{p}=0.000\right)$, small native solitary bees $\left(\mathrm{F}_{2}=24.52, \mathrm{p}=0.000\right)$, and native eusocial bees $\left(\mathrm{F}_{2}=\right.$ 35.9I, $\mathrm{p}=0.000)$ exhibited significantly different mean foraging rates in at least one city comparison, often with Cañas differing from both Liberia and Bagaces (see Tab. 2). Non-native eusocial bees (African honey bees) had significantly different occurrences in each city $\left(\mathrm{F}_{2}=38.50, \mathrm{p}\right.$ $=0.000$ ); they were highest in Liberia, intermediate in Bagaces, and lowest in Cañas (Tab. 2). Variability between the three cities validated the development of site- and guildspecific foraging models.

\section{Community foraging models}

Increasing resource abundance positively influenced the abundance and richness of foragers attracted to individual $T$. stans resources across the entire (all city) sample. The number of flowers per $T$. stans individual (FLW: $\mathrm{t}=5.48, \mathrm{p}=$ 0.000 ) and the number of other $T$. stans resources within a I0 metre radius (CON-SP I0: $t=1.99, p=0.049)$ were globally significant drivers of bee abundance at a site. Overall taxon richness was influenced only by the total number of flowers per resource (FLW: $\mathrm{t}=6.92, \mathrm{p}=0.000$ ). A cityspecific analysis of the drivers of bee visitation revealed further variability between the study sites. The summary of the multivariate regression models constructed for the bee community (total abundance and taxon richness) is displayed in Tab. 3, with more detailed models available in Appendix II.

In each city, abundance patterns were driven by a mix of resource characteristics and land use variables, however, in each case, the number of flowers per individual resource remained significant (FLW: Bagaces, $\mathrm{t}=2.82, \mathrm{p}=0.010$; Cañas, $\mathrm{t}=4.03, \mathrm{p}=0.000$; Liberia, $\mathrm{t}=4.10, \mathrm{p}=0.000)$. In Bagaces residential land use (RES; $t=2.27, p=0.032$ ) indicated increased bee visitor abundance; per count, on average 2.64 ( \pm I.I6) more bees were attracted to resources that were on residential land compared to commercial land. In Cañas, proximity to open space (OPEN: $\mathrm{t}=2.00, \mathrm{p}=$ $0.054)$ and an increasing distance from the wildland-urban interface (D WUI: $\mathrm{t}=2.00, \mathrm{p}=0.054$ ) positively correlated with increased bee abundance. In Liberia a shrub life form (SHRUB: $\mathrm{t}=2.26, \mathrm{p}=0.028$ ) was positively associated with increasing bee visitation, while open space was negatively associated (OPEN: $\mathrm{t}=-2 . \mathrm{I} 4, \mathrm{p}=0.037$ ). 


\begin{tabular}{|c|c|c|c|c|c|c|c|c|}
\hline \multirow{3}{*}{ Abundance } & \multirow{2}{*}{\multicolumn{3}{|c|}{$\begin{array}{c}\text { City } \\
\text { Comparison }\end{array}$}} & \multirow{3}{*}{$\frac{\text { Diff. }}{-0.609}$} & \multirow{3}{*}{$\begin{array}{l}\text { Std. } \\
\text { Error } \\
0.202\end{array}$} & \multirow{3}{*}{$\frac{p}{0.003^{* *}}$} & \multicolumn{2}{|c|}{$95 \% \mathrm{CI}$} \\
\hline & & & & & & & \multirow{2}{*}{$\frac{\text { Upper }}{-1.006}$} & \multirow{2}{*}{$\frac{\text { Lower }}{-0.212}$} \\
\hline & B & vs & C & & & & & \\
\hline & B & vs & $\mathrm{L}$ & -0.184 & 0.193 & 0.339 & -0.562 & 0.194 \\
\hline & $\mathrm{C}$ & vs & $\mathrm{L}$ & 0.425 & 0.184 & $0.02 \mathrm{I}$ & 0.063 & 0.786 \\
\hline Richness & B & vs & $\mathrm{C}$ & -0.218 & 0.056 & $0.000^{* x}$ & -0.327 & -0.109 \\
\hline & B & vs & $\mathrm{L}$ & -0.329 & 0.053 & $0.000^{* *}$ & -0.433 & -0.226 \\
\hline & $\mathrm{C}$ & vs & $\mathrm{L}$ & -0. II I & $0.05 \mathrm{I}$ & 0.028 & -0.210 & -0.012 \\
\hline \multirow[t]{3}{*}{ Large So litary } & B & vs & $\mathrm{C}$ & -0.773 & 0.148 & $0.000^{* x}$ & -1.063 & -0.482 \\
\hline & B & $v S$ & $\mathrm{~L}$ & -0.047 & $0.14 \mathrm{I}$ & $0.74 \mathrm{I}$ & -0.323 & 0.230 \\
\hline & $\mathrm{C}$ & $v s$ & $\mathrm{~L}$ & 0.726 & 0.135 & $0.000^{* *}$ & 0.462 & 0.990 \\
\hline \multirow{3}{*}{ Small So litary } & B & vs & $\mathrm{C}$ & 0.538 & 0.082 & $0.000^{* x}$ & 0.377 & 0.698 \\
\hline & B & vs & $\mathrm{L}$ & 0.133 & 0.078 & 0.088 & -0.020 & 0.286 \\
\hline & $\mathrm{C}$ & vs & $\mathrm{L}$ & -0.405 & 0.075 & $0.000^{* *}$ & $-0.55 \mathrm{I}$ & -0.258 \\
\hline \multirow{4}{*}{$\begin{array}{l}\text { Native } \\
\text { Eusocial }\end{array}$} & & & & & & & & \\
\hline & B & vs & $\mathrm{C}$ & $-0.52 \mathrm{I}$ & 0.076 & $0.000^{* x}$ & -0.670 & -0.373 \\
\hline & B & vs & $\mathrm{L}$ & 0.012 & 0.072 & 0.870 & -0.129 & 0.153 \\
\hline & $\mathrm{C}$ & vs & $\mathrm{L}$ & 0.533 & 0.069 & $0.000^{* *}$ & 0.398 & 0.668 \\
\hline \multicolumn{9}{|l|}{ Non-native } \\
\hline \multirow[t]{3}{*}{ Eusocial } & B & vs & $\mathrm{C}$ & 0.110 & 0.039 & $0.004^{* x}$ & 0.035 & 0.186 \\
\hline & B & vs & $\mathrm{L}$ & $-0.19 \mathrm{I}$ & 0.037 & $0.000^{* *}$ & -0.263 & -0.119 \\
\hline & C & vs & $\mathrm{L}$ & -0.302 & 0.035 & $0.000^{* *}$ & -0.370 & -0.233 \\
\hline
\end{tabular}

The number of flowers per individual $T$. stans resource consistently correlated with increased forager richness. This was the singular factor that influenced patterns in Liberia (FLW: $\mathrm{t}=4.49, \mathrm{p}=0.000$ ) and Cañas (FLW: $\mathrm{t}=3.64, \mathrm{p}=$ $0.00 \mathrm{I})$. Other variables including residential land use (RES: $\mathrm{t}$ $=3.76, \mathrm{p}=0.00 \mathrm{I})$ and distance to the wildland-urban interface (D-WUI: $\mathrm{t}=-2.33, \mathrm{p}=0.032$ ) were important in Bagaces. Residential land use predicted almost one additional taxon to be present per observation compared to commercial land use. Forager richness was also higher on resources closer to the wildland-urban edge.

\section{Guild specific resource usage}

Solitary bees-Floral abundance was consistently positively correlated to increased solitary bee visitation in each city (FLW: Bagaces, $\mathrm{t}=2.40, \mathrm{p}=0.025$; Cañas, $\mathrm{t}=4.67$, $\mathrm{p}$ $=0.000$; Liberia, $\mathrm{t}=2.97, \mathrm{p}=0.004)$, but was not the only factor that drove visitation patterns. A summary of the foraging models developed for each guild is presented in Tab. 3, with more detailed models presented in Appendix III. In Bagaces, residential land use significantly increased the number of solitary bees by $2.36( \pm 0.92)$ individuals per count compared to commercial land use (RES: $\mathrm{t}=2.58, \mathrm{p}=$ 0.0I6). In Cañas, an increasing distance from the wildlandurban interface (D WUI: $\mathrm{t}=2.80, \mathrm{p}=0.00 \mathrm{I}$ ) and a tree life form (TREE: $t=2.68, p=0.012$ ) significantly positively increased solitary bee numbers. In Liberia, there was a negative association with solitary bee foraging rates and proximity to open space (OPEN: $\mathrm{t}=-2.10, \mathrm{p}=0.04 \mathrm{I})$ and a positive correlation with resources that were considered shrubs (SHRUB: $\mathrm{t}=2.44, \mathrm{p}=0.018$ ). When solitary bees were examined by functional size guilds more specific patterns became evident.

Large bees-The overall occurrence of large solitary bees was significantly positively correlated with the number of flowers that a resource had (FLW: $\mathrm{t}=3.84, \mathrm{p}=0.000)$ and with the number of con-specific resources within 10 metres (CON-SP I0: $\mathrm{t}=2.23, \mathrm{p}=0.0 \mathrm{I5})$; both are measures of resource aggregation. In Bagaces, the foraging rates of large solitary bees were significantly positively influenced by the total number of flowers per individual resource (FLW: $\mathrm{t}=2.62, \mathrm{p}$ $=0.018$ ), residential land use (RES: $t=2.89, p=0.002)$, and decreasing distance to riparian areas (D RIP: $\mathrm{t}=-3.44, \mathrm{p}$ $=0.000)$. In Cañas, large solitary bee foraging rates were significantly positively correlated with resource characteristics (FLW: $\mathrm{t}=3.32, \mathrm{p}=0.002$ and TREE: $\mathrm{t}=2.5 \mathrm{I}, \mathrm{p}=0.018$ ) and distance to the wildland-urban interface (D WUI: $\mathrm{t}=$ 4.I0, $p=0.000)$. In Liberia, only the number of flowers per individual resource (FLW: $\mathrm{t}=2.00, \mathrm{p}=0.050$ ) was significant, with more large solitary bees visiting resources with greater floral abundance.

Small bees - The overall visitation rates of small solitary bees correlated significantly and positively with the number of flowers per individual resource (FLW: $\mathrm{t}=3.06, \mathrm{p}=0.003$ ) and with resource characteristics. Shrubs were preferred (SHRUB: $\mathrm{t}=3.07, \mathrm{p}=0.003$ ), with $0.63( \pm 0.2 \mathrm{I})$ more visitors per observation noted on shrubs as compared to hedge- and tree-like growth forms. The influence of floral abundance on this guild was not consistent across the three cities. Cañas was the only city in which floral abundance per resource significantly increased small bee visitation (FLW: $\mathrm{t}$ $=4.27, \mathrm{p}=0.000$ ); decreasing resource height (HEIGHT: $\mathrm{t}$ $=-2.74, p=0.010)$ was also a driving factor. In Liberia, a shrub life form (SHRUB: $\mathrm{t}=3.10, \mathrm{p}=0.003$ ) significantly positively correlated with small solitary bee visitation. An increasing distance from riparian areas (D RIP: $\mathrm{t}=3.2 \mathrm{I}, \mathrm{p}=$ 0.000 ) was the only significant descriptor of small solitary bee visitation in Bagaces; small bee numbers were inversely related to nearness to riparian habitats. 
Eusocial bees-The local community of eusocial bees contains many native stingless bees (Nannotrigona perilampoides, Plebeia sp., Plebeia frontais, Tetragonisca angustata, Trigona fulviventris, and Trigona sp.), but also the non-native African honey bee (Apis mellifera scutellata). In the pooled city analysis, eusocial bees were positively influenced by the number of flowers per resource (FLW: $\mathrm{t}=$ 5.97, $\mathrm{p}=0.000)$ and by the distribution of con-specific resources within a I0 metre radius (CON-SP I0: $\mathrm{t}=2.65, \mathrm{p}$ $=0.009)$. Flowers per resource remained an important influence on visitation rates of eusocial bees in all of the study cities (FLW: Bagaces, $\mathrm{t}=3.4 \mathrm{I}, \mathrm{p}=0.002$; Cañas, $\mathrm{t}=2.72$, $\mathrm{p}$ $=0.00 \mathrm{I}$; Liberia, $\mathrm{t}=5.28, \mathrm{p}=0.000)$. In Bagaces the life form was significant, with hedges attracting more visitors than shrubs or trees (HEDGE: $\mathrm{t}=1.86, \mathrm{p}=0.075$ ), while in Cañas resource distribution (CON-SP I0: $\mathrm{t}=\mathrm{I} .94, \mathrm{p}=$ 0.062) was important, with more aggregated resources attracting more eusocial bees. In Liberia the location of the resource within the urban landscape correlated with increasing visitation ( $\mathrm{D}$ WUI: $\mathrm{t}=2.50, \mathrm{p}=0.015$ ), with resources located closer to the perimeter receiving more visits.
Native eusocial bees-Native eusocial bees were influenced exclusively by resource quantity (FLW: $\mathrm{t}=3.25$, $\mathrm{p}$ $=0.00)$ and distribution (CON-SP I0: $\mathrm{t}=3.32, \mathrm{p}=0.049)$ in the pooled city sample. Floral abundance per resource remained significantly positively influential in Bagaces and Liberia (FLW: $\mathrm{t}=2.35, \mathrm{p}=0.000$ and $\mathrm{t}=1.96, \mathrm{p}=0.055$, respectively), but not in Cañas where proximity to open space (OPEN: $\mathrm{t}=3 . \mathrm{I}, \mathrm{p}=0.004$ ) and life form (HEDGE: $\mathrm{t}=$ $2.02, p=0.052)$ were the significant drivers of foraging rates.

Non-native eusocial bees-Floral abundance per resource was a clear and consistent factor in describing African honey bee occurrence in each city (FLW: Bagaces, $\mathrm{t}=2.63, \mathrm{p}=$ 0.015; Cañas, $\mathrm{t}=$ I.82, $\mathrm{p}=0.072$; Liberia, $\mathrm{t}=6.77, \mathrm{p}=$ $0.000)$, but landscape variables also correlated significantly in some cities. Residential land use had a particular significant positive association with increased occurrence in Liberia (RES: $\mathrm{t}=3.2 \mathrm{I}, \mathrm{p}=0.002$ ), as did an increasing distance from the wildland (D WUI: $t=4.39, \mathrm{p}=0.000$ ); neither of these variables impacted local native bee species.

\begin{tabular}{|c|c|c|c|c|}
\hline & All Cities & Bagaces & Cañas & Liberia \\
\hline \multicolumn{5}{|l|}{ Community: } \\
\hline Abundance & $\begin{array}{l}(+) \text { FLW } \\
(+) \text { CON-SP I0 }\end{array}$ & $\begin{array}{l}(+) \text { FLW } \\
(+) \text { RES }\end{array}$ & $\begin{array}{l}(+) \text { FLW } \\
(+) \text { OPEN⿱ } \\
(+) \text { D WUI: }\end{array}$ & $\begin{array}{l}(+) \text { FLW } \\
(-) \text { OPEN } \\
(+) \text { SHRUB }\end{array}$ \\
\hline Richness & $(+) \mathrm{FLW}$ & $\begin{array}{l}(+) \text { FLW } \\
(+) \text { RES } \\
(-) \text { CON-SP IO } \\
(-) \text { D WUI } \\
(-) \text { SHRUB }\end{array}$ & $(+) \mathrm{FLW}$ & $(+) \mathrm{FLW}$ \\
\hline \multicolumn{5}{|l|}{ Guilds: } \\
\hline Solitary & $(+) \mathrm{FLW}$ & $\begin{array}{l}(+) \text { FLW } \\
(+) \text { RES }\end{array}$ & $\begin{array}{l}(+) \text { FLW } \\
(+) \text { D WUI } \\
(+) \text { TREE }\end{array}$ & $\begin{array}{l}(+) \text { FLW } \\
(-) \text { OPEN } \\
(+) \text { SHRUB }\end{array}$ \\
\hline Large & $\begin{array}{l}(+) \text { FLW } \\
(+) \text { CON-SP IO }\end{array}$ & $\begin{array}{l}(+) \text { FLW } \\
(+) \text { RES } \\
(-) \text { D WUI } \\
(-) \text { D RIP }\end{array}$ & $\begin{array}{l}(+) \text { FLW } \\
(+) \text { D WUI } \\
(+) \text { TREE }\end{array}$ & $\begin{array}{l}(+) \text { FLW } \\
(-) \text { OPEN }\end{array}$ \\
\hline Small & $\begin{array}{l}(+) \text { FLW } \\
(-) \text { OPEN } \\
(+) \text { SHRUB }\end{array}$ & $(-)$ D RIP & $\begin{array}{l}(+) \text { FLW } \\
(-) \text { HEIGHT }\end{array}$ & $(+)$ SHRUB \\
\hline Eusocial & $\begin{array}{l}(+) \text { FLW } \\
(+) \text { CON-SP IO }\end{array}$ & $\begin{array}{l}(+) \text { FLW } \\
(+) \text { HEDGE: }\end{array}$ & $\begin{array}{l}(+) \text { FLW } \\
(+) \text { CON-SP IO }\end{array}$ & $\begin{array}{l}(+) \text { FLW } \\
(+) \text { D WUI }\end{array}$ \\
\hline Native & $\begin{array}{l}(+) \mathrm{FLW} \\
(+) \mathrm{CON}-\mathrm{SP}\end{array}$ & $(+) \mathrm{FLW}$ & $\begin{array}{l}(+) \text { OPEN } \\
(+) \text { HEDGE: }\end{array}$ & $\begin{array}{l}(+) \text { FLW\$ } \\
(-) \text { RES }\end{array}$ \\
\hline Non-native & $\begin{array}{l}(+) \text { FLW } \\
(+) \text { RES } \\
(+) \text { D WUI }\end{array}$ & $\begin{array}{l}(+) \text { FLW } \\
(+) \text { D RIP }\end{array}$ & $(+)$ FLW & $\begin{array}{l}(+) \text { FLW } \\
(+) \text { RES } \\
(+) \text { CON-SP I0 } \\
(+) \text { D WUI }\end{array}$ \\
\hline
\end{tabular}

ТАВ 3: Summary of the pooled and individual city bee visitation models for the total community (abundance and taxon richness) and the individual bee guilds that are using $T$. stans as a pollen and nectar resource in the small and developing urban landscapes of Guanacaste, Costa Rica. All of the variables shown are significant at the $\alpha=$ 0.05 level unless indicated by $(\$)$ where they are significant at $\alpha=$ 0.08 . Variable abbreviations are as follows: FLW $=$ total flowers, CON-SP IO $=$ the number of other T. Stans within a IO metre radius of the sampled resource, RES = residential land use, OPEN = proximity to open space, D WUI $=$ distance to the wildland-urban interface, and D RIP = distance to riparian areas. The life form of the resource is indicated as a TREE, SHRUB, or HEDGE. The + or sign next to the variable in parenthesis indicates the direction of correlation. The explicit models for each taxon group are presented in Appendices II and III. 


\section{DISCUSSION}

Bees using T. stans as a pollen and nectar source in the urban landscapes of Northwestern Costa Rica preferentially visited resources with more abundant flowers, irrespective of their location in the urban landscape. The importance of characteristically anthropogenic variables was minimal, indicating that bees were generally not influenced by the urban matrix. Similar trends highlighting the greater importance of floral resources are emerging from studies conducted elsewhere (Colla et al. 2009; Werrell et al. 2009; Matteson \& Langellotto 20I0), further supporting the idea that the constructed elements of the urban landscape generally do not interfere with the occurrence and foraging of bees. The preferences of individual functional bee groups examined in this study are generally consistent with this trend, but also indicated that organism size and other life history characteristics are responsible for some unique responses to modified habitats.

Solitary bees are the dominant and most diverse assemblage of bees in the tropical dry forest (Frankie \& Vinson 2004). Larger solitary bees have been documented to preferentially visit flowering trees, while smaller bodied species visit more herbaceous forms (Frankie \& Vinson 2004). Within urban environments both size guides can be found visiting similar resources (Wojcik 2009). In this study, large bees responded with increased foraging at $T$. stans individuals with more flowers and at those that were clustered with other con-specifics - both are measures of resource aggregation at different scales. The occurrence of large bees in these landscapes may be influenced by the principals of energetics and optimal foraging. Larger species with increased metabolic needs have been shown to pattern their resource visitation to favour nearby patches of flowers, optimizing the energy required for flight with that acquired from nectar (Heinrich 1979).

Small bees in this study were more likely to visit $T$. stans resources with abundant flowers, but were also influenced by the life form of the resource, foraging in larger numbers on lower-growing resources that were shrubs. Vertical stratification was recorded by Roubik (1993) in the canopy of tropical forests near this study region and is suggested as a strategy to reduce direct competition. The observed preference for lower-growing resources could indicate that smaller bees are employing vertical stratification in an effort to reduce competition and exploit resources that larger species are not visiting. The proximity of a food resource to open space, riparian areas, and the wildland-urban interface (edge of the city) also correlated significantly with the number of small solitary bees recorded. Distance-based foraging responses in small bees in these landscapes could be due to dispersal limitations. The dispersal range from nest to food sites of small bees is thought to be 250 metres (Greenleaf et al. 2007), but this is likely a maximum capability and not an optimum range as indicated by Zurbuchen et al. (2010) who found reduced fitness effects as nest distance increased from food sources within this range. Areas of nearby natural habitat present more nesting opportunities for species such as Agapostemon nasutus and Halictus lutescens that commonly nest in the ground (Michener 2000), and these species would preferentially forage on more proximal $T$. stans resources to improve fitness.

\section{The importance of urban variables}

Certain landscape and habitat characteristics are unique to cities. Urban fauna must interact with features that wildland species do not experience, which leads urban ecologists to question if these unique urban habitat elements have a significant or corresponding unique effect on resident species. Although the results of this study generally indicated little to no influence from anthropogenic variables, residential land use was shown to have a significant and large impact on one particular group of bees, African honey bees, nearly doubling their occurrence. Residential areas have been noted by many authors as sites of increased bee richness due to the diversity of the floral resource base located in ornamental gardens (Tommasi et al. 2004; Frankie et al. 2005; Winfree et al. 2009). Others have found that floral richness per se does not strictly correlate with individual species occurrence patterns in gardens (Werrel et al. 2009) as most bees possess narrow feeding ranges (Michener 2000) or restrict daily foraging to specific plants (Heinrich 1979). In this study, only generalist species displayed significantly increased abundance rates at residential garden sites, supporting findings that indicate floral diversity patterns do not universally increase bee occurrence.

Characteristics of the urban matrix and peri-urban landscape may have a unique or combined influence on bee visitation within guilds that respond to different spatial scales. Steffan-Dewenter et al.'s (2002) examination of bees in complex landscapes indicated heterogeneous and equally complex responses that were scale depended and guildspecific; similar responses might be occurring in the urban systems studied here. Bagaces and Liberia have the most similar patterns of per count bee visitation and species occurrences and both cities are situated within a similar regional land use dominated by cattle grazing and punctuated by native dry forest remnants. Cañas is different, sitting in the centre of agricultural intensification. On a finer scale, Bagaces and Liberia are interspersed with more streams and riparian areas while Cañas has a higher density of housing units, but also has more managed public parks. Given the city-specific variability seen in this study, it is the author's opinion that generalizing the responses of bees to 'urban' areas is premature. Few studies have compared multiple urban landscapes, and fewer still have focused on meso- and microscale landscape characteristics, especially in tropical systems. The trends outlined here provide a starting point to further studies of comparative bee ecology and behaviour in a rapidly growing landscape type.

\section{ACKNOWLEDGEMENTS}

Thanks to Meaghan Jastrebski and Laura Fine for their assistance with data collection in the field. Financial support for this work was provided by the Schwabacher Memorial Scholarship in Forestry, and made trips into the field possible. The staff of the GIF (ESPM, University of California Berkeley) provided technical support and advice for GIS analysis. Thanks to Greg Biging for continued advice on statistical modelling. Thanks also to Patina Mendez, Maria Wojcik, Jennifer Tsang, Laurie Davies Adams, and 
Sean Fine for early and final reviews of the manuscript text. Constructive comments from the two reviewers improved the manuscript and are much appreciated. Special thanks to Joe R. McBride for supporting this work and pushing to see it complete.

\section{APPENDICES}

Additional supporting information may be found in the online version of this article.

APPENDIX I: The resource and landscape variables used in backward stepwise regression model development.

APPENDIX II: The backward stepwise regression models describing bee visitor abundance and taxon richness at $T$. stans resources and across all of the and at each individual study site.

APPENDIX III: The backward stepwise regression models describing the occurrence individual guilds at $T$. stans resources and across all of the cities and at each individual study site.

\section{REFERENCES}

Ahrne K, Bengtsson J, and Elmqvist T (2009) Bumble Bees (Bombus spp.) along a gradient of increasing urbanization. PLoS 4(5): e5574:I-9.

Antonini Y, Costa RG, and Martins RP (2006) Floral preferences of a neotropical stingless bee, Melipona quadrifasciata Lepeletier (Apidad: Meliponia) in an urban forest fragment. Brazilian Journal of Biology 66(2A): 463-47I.

Brosi BJ, Daily GC, and Ehrlich PR (2007) Bee Community Shifts With Landscape Context In A Tropical Countryside. Ecological Applications 17(2): 4I8-430.

Buchmann S, and Nabhan GP (I996) The Forgotten Pollinators. Island Press, New York.

Buchmann SL, and Ascher JS (2005) The plight of pollinating bees. Bee World 86: 7I-74

Cane J, Minckley R, Kervin L, and Roulston T (2005) Temporally persistent patterns of incidence and abundance in a pollinator guild at annual and decadal scales: the bees of Larrea tridentata. Biological Journal of the Linnean Society 85: 319-329.

Cane J, Minckley R, Kervin L, Roulston T, and Williams N (2006) Complex responses within a desert bee guild (Hymenoptera: Apiformes) to urban habitat fragmentation. Ecological Applications I6(2): 632-644.

Colla SR, Willis E, and Packer L (2009) Can green roofs provide habitat for urban bees (Hymenoptera: Apidae)? Cities and the Environment 2(I): I2 [online] URL: http://escholarship.bc.edu/cate/vol2/issI/4/.

Collevatti RG, Schoereder JH, and Campos LAO (2000) Foraging behavior of bee pollinators on the tropical weed Triumfetta semitriloba: Flight distance and directionality. Revista Brasileira de Biologia 60(I): 29-37.

ESRI (I999) ArcGIS v 9.3 [online] URL: www.esri.com.

Frankie GW, and Vinson BS (2004) Conservation and Environmental Education in Rural Northwestern Costa Rica. In: Frankie GW, Mata A, and Vinson SB (eds) Biodiversity Conservation in Costa Rica, University of California Press, Berkeley, pp 247-256.

Frankie GW, Rizzardi M, Vinson BS, and Griswold T (2009a) Decline in bee diversity and abundance from 1972-2004 on a flowering leguminous tree, Andira inermis in Costa Rica at the interface of disturbed dry forest and the urban environment. Journal of the Kansas Entomological Society 82(I): I-20.

Frankie GW, Thorp RW, Hernandez JL, Rizzardi M, Ertter B, Pawelek JC, Witt SL, Schindler M, Coville R, and Wojcik VA (2009b) Native bees are a rich natural resource in urban California gardens. California Agriculture 63(3): I I3-I20.

Frankie GW, Thorp RW, Schindler M, Hernandez JL, Ertter B, and Rizzardi M (2005) Ecological patterns of bees and their host ornamental flowers in two northern California cities. Journal of the Kansas Entomological Society 78: 227-246.

Frankie GW, Thorp RW, Schindler MH, Ertter B, and Przybylski M (2002) Bees in Berkeley? Fremontia 30(3-4): 50-58.

Frankie GW, Vinson BS, Rizzardi M, Griswold T, O'Keefe S, and Snelling RR (1997) Diversity and abundance of bees visiting a mass flowering tree in disturbed seasonal dry forest, Costa Rica. Journal of the Kansas Entomological Society 70: 28I-296.

Greenleaf SS, Williams N, Winfree R, and Kremen C (2007) Bee foraging ranges and their relationship to body size. Oecologia I53: 589-596.

Hammel B (2005) Plantas ornamentales nativas de Costa Rica Native Ornamental Plants. Instituto Nacional de Biodiversidad (INBio), San Jose.

Heard MS, Carvell C, Carreck NL, Rothery P, Osborne JL, and Bourke AFG (2007) Landscape context not patch size determines bumble-bee density on flower mixtures sown for agrienvironmental schemes. Biology Letters 3: 638-64I.

Heinrich B (1979) Bumble bee Economics. Harvard University Press, Cambridge.

Hisamatsu M, and Yamane S (2006) Fuanal makeup of wild bees and their flower utilization in a semi-urbanized area in central Japan. Entomological Science 9: I37-I45.

INEC (Instituto Nacional de Estadistica y Censos) Costa Rica (2000) del V Censo Nacional de Vivienda [online] URL: http://www.inec.go.cr/.

Jha, Shalene and J Vandermeer (2009) Contrasting bee foraging response to resource scale and local habitat management. Oikos I I8: I I74-II80.

Kremen C, Williams N, and Thorp RW (2002) Crop pollination from native bees at risk from agricultural intensification. PNAS 99(26): I6812-16816.

Liu H, and Koptur S (2003) Breeding system and pollination of a narrowly endemic herb of the Lower Florida Keys: impacts of the urban-wildland interface. American Journal of Botany 90(8): I I80-I I87.

Matteson KC, and Langellotto GA (2010) Determinates of inner city butterfly and bee species richness. Urban Ecosystems I3: 333347.

Matteson KC, Ascher JS, and Langellotto GA (2008) Bee Richness and Abundance in New York City Urban Gardens. Annals of the Entomological Society of America IOI(I): I40-I50.

McIntyer NE, and Hostetler ME (200I) Effects of urban land use on pollinator (Hymenoptera: Apoidea) communities in a desert metropolis. Basic and Applied Ecology 2: 209-2I8.

Michener CD (2000) The Bees of the World. Johns Hopkins University Press, Baltimore.

Nates-Parra G, Parra A, Rodrigues A, Baquero P, and Velez D (2006) Wild bees (Hymenoptera: Apoidea) in urban ecosystems: preliminary survey in the city of Bogota and its surroundings. Revista Colombiana de Entomologia 32: 77-84.

National Research Council (NRC) - National Academies of Science: Committee on the Status of Pollinators in North America NRC (2007) Status of Pollinators in North America. The National Academies Press, Washington, D.C..

Ollerton J, Winfree R, and Tarrant S (20I I) How many flowering plants are pollinated by animals? Oikos I20: 32 I-326. 
Owen J (1991) Ecology of a Garden, The First Fifteen Years. Cambridge University Press, Cambridge.

Roubik DW (1993) Tropical Pollinators in the Canopy and Understory: Field data and theory for stratum "preferences". Journal of Insect Behavior 6(6): 659-673.

Saure C (1996) Urban habitats for bees: the example of the City of Berlin. In: Matheson A, Buchmann SL, O'Toole C, Westrich P, and Williams IH (eds) The conservation of bees, Academic Press, New York, pp 47-54.

Silva CI, Augusto SC, Sofia SH, and Moscheta IS (2007) Bee diversity in Tecoma stans (L.) Kunth (Bignoniaceae): Importance for pollination and fruit production. Neotropical Entomology 36(6): 33I-34I.

SPSS (2007) SPSS v 6 [online] URL: www.spss.com.

Steffan-Dewenter I, and Kuhn A (2003) Honey bee Foraging in Differentially Structured Landscapes. Proceedings: Biological Sciences 270(I5I5): 569-575.

Steffan-Dewenter I, Munzenberg U, Burger C, Thies C, and Tscharntke T (2002) Scale-dependent effects of landscape context on three pollinator guilds. Ecology 83(5): I42I-I432.

Tommasi D, Miro A, Higo HA, and Winston ML (2004) Bee diversity and abundance in an urban setting. Canadian Entomologist I36(6): 85I-869.
Werrell PA, Langellotto GA, Morath SU, and Matteson KC (2009) The influence of garden size and floral cover on pollen deposition in urban community gardens. Cities and the Environment 2(I): 16 [online] URL: http://escholarship.bc.edu/cate/vol2/issI/6.

Winfree R, Aguilar R, Vazquez DP, LeBuhn G, and Aizen MA (2009) A meta-analysis of bees' responses to anthropogenic disturbance. Ecology 90(8): 2068-2076.

Winfree R, Griswold T, and Kremen C (2007) Effect of Human Disturbance on Bee Communities in a Forested Ecosystem. Conservation Biology 2I(I): 213-223.

Wojcik VA (2009) Bees in urban landscapes: An investigation of habitat utilization. Ph.D. Dissertation, University of California, Berkeley Department of Environmental Science, Policy, \& Management: i-204.

Wojcik, VA (20II) The urban bees (Hymenoptera: Apoidea) of Tecoma stans (Bignoniaceae): Phenology and community composition in three tropical dry forest cities. Journal of the Kansas Entomological Society In press.

Zuchowski W (2007) Tropical Plants of Costa Rica. Zona Tropicala, Ithaca.

Zurbuchen A, Chessman S, Klaiber J, Muller A, Hein S, and Dorn S (2010) Long foraging distances impose high costs on offspring production in solitary bees. Journal of Animal Ecology 79: 674681 